\title{
Chemical review and studies related to species from the genus Tynanthus (Bignoniaceae)
}

\author{
Fernanda Colombi Cansian, ${ }^{1 *}$, Francis José Zortéa Merino², Josiane de Fátima Gaspari Dias, \\ Sandra Maria Warumby Zanin ${ }^{1}$, Obdulio Gomes Miguel², Marilis Dallarmi Miguel ${ }^{1}$
}

\author{
${ }^{1}$ Pharmacy Department, Pharmacotechnics Laboratory, Federal University of Paraná, Curitiba, PR, Brazil, ${ }^{2}$ Pharmacy \\ Department, Phytochemical Laboratory, Federal University of Paraná, Curitiba, PR, Brazil
}

\begin{abstract}
Species from the Bignoniaceae Family, including the genus Tynanthus, are very prevalent in the tropical Americas, with specimens found in a large part of the Brazilian territory. These plants are commonly used in traditional medicine for several purposes, and some studies have described their chemical structure, in addition to other reports related to some species from this genus. This review aimed to gather information from published works concerning species of the genus Tynanthus, as well as to detect flaws in research related to these plants, which may have great biological and pharmaceutical importance. Also, this review points out some common chemical characteristics of these species, providing information that may help new researchers to improve their knowledge about these plants.
\end{abstract}

Uniterms: Tynanthus/pharmacognosy. Tynanthus/phytochemistry. Tynanthus/biological activity. Bignoniaceae/pharmacognosy. Bignoniaceae/phytochemistry. Medicinal plants.

\begin{abstract}
As espécies da família Bignoniaceae possuem grande predominância na região da América tropical e entre elas, as espécies do gênero Tynanthus, com representantes em grande parte do território brasileiro. Estas plantas são comumente utilizadas na medicina tradicional para os mais diversos fins e algumas pesquisas já descrevem a constituição química além de outros estudos relacionados a alguns integrantes deste gênero. Este trabalho de revisão teve como objetivo reunir informações de trabalhos publicados a respeito das espécies do gênero Tynanthus e permitiu detectar a deficiência nas pesquisas relacionadas a estas plantas, que podem trazer consigo grande importância biológica e farmacológica. Além disto, este trabalho tornou possível apontar algumas características químicas em comum entre as espécies, trazendo informações que podem auxiliar novos pesquisadores que procuram melhorar seus conhecimentos acerca destas plantas.
\end{abstract}

Unitermos: Tynanthus/pharmacognosy. Tynanthus/phytochemistry. Tynanthus/biological activity. Bignoniaceae/pharmacognosy. Bignoniaceae/phytochemistry. Medicinal plants.

\section{INTRODUCTION}

The Bignoniaceae family gathers 82 genus and 827 species (Lohmann, Ulloa, 2007), which are usually spontaneous tropical species in South America, including trees, vines, bushes and rarely herbs (Di Stasi, 2002).

Gentry (1980) was a pioneer in detailing the taxonomy of the family, later reviewed by Spangler and Olmstead (1999). In a more recent description by Fischer et al. (2004), there are seven of the eight clades, which

\footnotetext{
*Correspondence: F.C Cansian. Departamento de Farmácia, Laboratório de Farmacotécnica. Universidade Federal do Paraná. Rua Pref. Lothário Meissner, 3400, Jardim Botânico - 80210-170 - Curitiba - PR, Brasil. E-mail: fecolombi@hotmail.com
}

were proposed before: Bignonieae, Coleeae, Crescentieae, Eccremocarpeae, Oroxyleae, Tecomeae and Tourrettieae. Two clades, Bignonieae and Crescentiinae, represent more than $80 \%$ of the species from the family (Olmstead et al., 2009). Lohmann (2006) organizes genus Tynanthus species within the Bignonieae tribe.

Tynanthus was originally described by Miers (1863) and later by Bureau (1868). The species from this genus are distributed throughout tropical America, mainly in rainforests, from Mexico to southern Brazil, and in several countries, including Costa Rica, Guatemala, Panama, Dominican Republic, French Guiana, Venezuela, Bolivia, Ecuador, Peru, Colombia, Argentina and Paraguay (Reitz, 1974; Lohmann, Ulloa, 2007). 
The species of this genus are vines, popularly known as clove vine (cipó-cravo), due to the strong smell of Indian clove that emanates when the stems or leaves are cut or macerated (Lopes et al., 2008). Lohman (2006), in his description of the morphological synapomorphy of Tynanthus, noted that besides its smell, it shows bilabiate flowers with two upper lobes fused and fruits with raised margins, information that helped in the phylogeny reconstruction of these species.

In traditional medicine, Tynanthus species are used for several purposes, for example, for the treatment of rheumatism and diabetes, besides their application as a stimulant, aphrodisiac, carminative and anthelmintic, Most of these properties have been already verified by specialists (Vilegas et al., 1993; Brack, 1999).

Because of their already known popular use, this review had the objective of gathering information from scientific studies related to the genus Tynanthus, aiming to improve the knowledge about their chemical constitution, biological activities and other issues related to these species. With this information, it will be possible to identify deficiencies in studies involving the members of this genus, and ultimately serve as a tool for research aiming to assess the unstudied properties of these plants.

\section{RESEARCH METHODOLOGY}

The references were tracked based on a 20-year period, and were obtained from databases such as Biological Abstract and Chemical Abstract. In addition, references in the Scientific Electronic Library Online (Scielo), Medline/Pubmed and other internet sites were searched, without a time limitation.

\section{Recognized species from the genus Tynanthus}

According to the Missouri Botanical Garden, The New York Botanical Garden and The Board of Trustees of the Royal Botanic Gardens (Lohmann, Ulloa, 2007), 15 recognized species in this genus are registered, and are listed in Table I.

\section{SPECIES WITHOUT STUDIES}

When searching for studies related to the genus Tynanthus, no results were found for the following species: Tynanthus croatianus A.H. Gentry, Tynanthus goudotianus Bureau, Tynanthus labiatus (Cham.) Miers, Tynanthus macranthus L. O. Williams, Tynanthus polyanthus
TABLE I - Recognized species from the genus Tynanthus

\section{Species}

Tynanthus cognatus (Cham.) Miers

Tynanthus croatianus A.H. Gentry

Tynanthus elegans Miers

Tynanthus fasciculatus (Vell.) Miers

Tynanthus goudotianus Bureau

Tynanthus guatemalensis Donn. Sm

Tynanthus labiatus (Cham.) Miers

Tynanthus macranthus L. O. Williams

Tynanthus micranthus Mello ex K. Schum

Tynanthus panurensis (Bureau) Sandwith

Tynanthus polyanthus (Bureau ex Baill.) Sandwith

Tynanthus pubescens A.H. Gentry

Tynanthus sastrei A.H. Gentry

Tynanthus schumannianus (Kuntze) A.H. Gentry

Tynanthus villosus A.H. Gentry

Source: (Lohmann, Ulloa, 2007)

(Bureau ex Baill.) Sandwith, Tynanthus pubescens A.H. Gentry, Tynanthus sastrei A.H. Gentry and Tynanthus villosus A.H. Gentry.

\section{Tynanthus cognatus (Cham.) Miers}

This species is commonly found in Brazil, in the northeastern (Bahia), southeastern (Espírito Santo, Minas Gerais, Rio de Janeiro and São Paulo) and southern regions (Paraná, Rio Grande do Sul and Santa Catarina) (Lohmann, 2014a).

Lima, Pace and Angyalossy (2010), who studied issues concerning environmental and morphoanatomical aspects, especially those influencing vine growth, based their work on the characteristics of T. cognatus, and compared them to 31 other Bignonieae species. Thus, the stem anatomy, the seasonality of the formation and differentiation of secondary tissues and the influence on the change rate in xylem development were studied this species in order to identify general growth standards in vines from this tribe. Some discoveries were made, among them the change activity during the end of the rainy season, in contrast to what is known about tropical trees and bushes. It was concluded that the change is a response to the environmental changes and that the growth rings are annual, happening in a period of roughly two months, which may explain the fact that the vines possess narrow rods. 


\section{Tynanthus elegans Miers}

T. elegans Miers is a native plant of Brazil, found in the southeastern (Espírito Santo, Minas Gerais, Rio de Janeiro and São Paulo) and southern (Paraná, Rio Grande do Sul and Santa Catarina) regions (Lohmann, 2014b).

This species was highlighted in a phytosociological survey of a liana community in a seasonal semideciduous forest, located in São Carlos, São Paulo, Brazil, which showed a prevalence of species from the Bignoniaceae, Malpighiaceae, Sapindaceae and Apocynaceae families. The Bignoniaceae family comprised a major percentage in terms of species numbers, and T. elegans was had the third highest importance value (IV), a parameter which is directly related to the relative dominance (RD) in the studied region (Hora, Soares, 2002), which justifies, at least in part, its prevalence in the southeastern region of Brazil.

\section{Tynanthus fasciculatus (Vell.) Miers}

T. fasciculatus shows a relatively restricted distribution, occurring in the Brazilian southeast, in Minas Gerais, São Paulo and Rio de Janeiro (Lohmann, 2014c).

The Brazilian Pharmacopoeia (Farmacopéia, 1929) describes T. fasciculatus and T. elegans as carminative plants, and Correa (1974) reports that the population uses these plants for aphrodisiac purposes, also citing their toxic effects.

Vilegas and colleagues (1993) showed in their studies the presence of coumarins, phenylpropanoids and steroids ( $\beta$-sitosterol- $\beta$-D-glucoside) (Figure 1) in the chemical constitution of $T$. fasciculatus, citing its use in traditional medicine as a stimulant, aphrodisiac, carminative and anthelmintic, the latter based on studies by Amorim et al. (1991), who demonstrated anthelmintic action in reducing the number of Oxyuridae in mice naturally infected by this parasite.

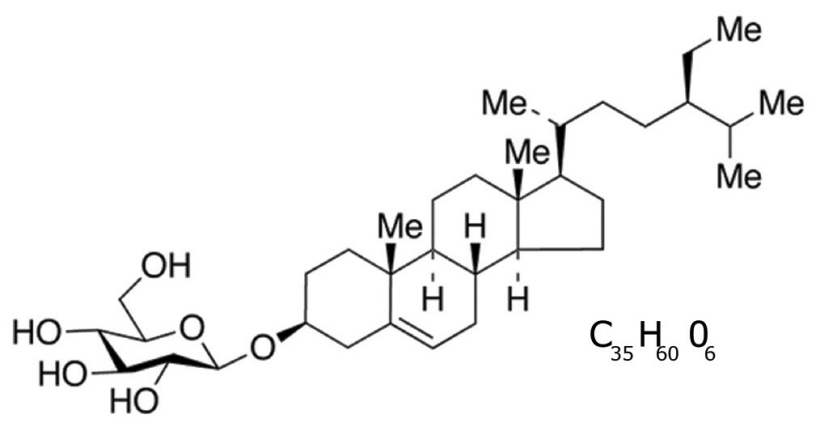

FIGURE 1 - Chemical and structural formula of $\beta$-sitosterol- $\beta$ D-glucoside (Vilegas et al., 1993).
A report from Vilegas et al. (1994) reinforced the presence of coumarins in all parts of the plant. Besides coumarin, melilotic acid and its derivatives were identified, as well as the phytosteroid stigmasterol, in the hexanic extract from roots. According to Carvalho et al. (2009), T. fasciculatus also contains flavonoids, cardiotonic heterosides and tannins. This same study showed high toxicity of the stem's aqueous extract to the microcrustacean Artemia salina.

The growth of $T$. fasciculatus seedlings was evaluated with the purpose of showing the location and characteristics of the forest where this plant develops best. It was verified that the forest edge was the location where the seedlings developed best, showing $100 \%$ survival and the greatest lengths and numbers of leaves. Only in this treatment was there development of tendrils in seedlings, which exceeded $80 \mathrm{~cm}$ in length (Lopes et al., 2008).

Because of the traditional application of this plant as an aphrodisiac, Melo et al. (2010) proposed in their study to evaluate the morphometry of male reproductive organs in adult male Wistar rats after treatment with an infusion of T. fasciculatus stems. In dose of $200 \mathrm{mg} / \mathrm{animal} / \mathrm{day}$, a significant increase in testicular parenchyma weight was observed, as well as an increase in the volume and total length of the seminiferous tubules and, as a consequence of this, an increase in sperm production.

\section{Tynanthus guatemalensis Donn. Sm}

T. guatemalensis is distributed from Mexico to Guatemala (Tropicos, 2014a). It presents in its chemical constitution saponins, anthocyanins and flavonoids in the stem, as demonstrated in a study by Miranda-Cruz et al. (2012), which also showed the antimicrobial activity of a hexane extract of its leaves against Bacillus cereus ATCC 11778.

Besides the antimicrobial activity of $T$. guatemalensis, Ferrier and colleagues (2013) reported its efficacy for the treatment of diabetes, based on ethnobotanical information from Mayan healers in the Mesoamerica region. Such activity was confirmed by in vitro tests which evaluated the inhibition of the formation of advanced glycation endproducts (AGE), substances which are considered to be important pathogenic mediators of diabetic complications. Extractions of milled T. guatemalensis wood were made with solvents of increasing polarity (hexane, ethyl acetate, and methanol). The extracts were assayed, and activity was found mainly in the ethyl acetate fraction, in a comparable way to the positive control, quercetin, known to possess activity as an AGE inhibitor.

UPLC-MS-QToF analysis of the crude extract of $T$. 
guatemalensis confirmed the presence of katchimoside analogs, 4-hydroxybenzoate and salicylic acid. In addition, verbacoside was identified by HPLC-MS-QTRAP in the ethyl-acetate extract and eugenol was detected by GC-MS in the essential oil (Ferrier, 2014).

\section{Tynanthus micranthus Mello ex K. Schum}

This plant is commonly found in Brazil, in the state of Paraná, as well as in the southeastern (São Paulo) and midwestern (Mato Grosso do Sul) regions (Lohmann, 2014d).

The study from Souza, Santos and Moscheta (2010) reported the morphoanatomical flower characteristics of three Bignoniaceae family species, including $T$. micranthus in the comparative study. They concluded that, although the flowers are structurally similar, there are significant differences in some characters, which allow their identification, for example the color and shape of the corolla, the number of cell layers in the perianth, and the types of trichomes in the perianth, among other characteristics.

The substances $\beta$-sitosterol and apigenin were isolated from T. micranthus, as well as chemical groups such as flavonoids (dihidroflavonoids and leucoanthocyanidins), steroids and/or triterpenoids, heterosidic anthraquinones (Cansian et al., 2012) and eugenol in the essential oil (Custódio et al., 2010).

The same study by Cansian et al. (2012) showed that some fractions are toxic against Artemia salina in a number of concentrations, suggesting care in the administration of the extracts of this plant. These preparations were also tested against some bacterial strains, and the results showed activity of the crude extract from the root against $E$. coli, whereas the crude extract from the stem was effective against $S$. aureus, $P$. aeruginosa and $E$. coli and the crude extract from the leaves was effective against $S$. aureus and $P$. aeruginosa, all of them with a minimal inhibitory concentration of $1000 \mu \mathrm{g} / \mathrm{mL}$. Custódio et al., 2010 had previously evaluated the antimicrobial activity of the essential oil of T. micranthus, whose bioautography indicated eugenol as the substance responsible for its activity against Cladosporium herbarum.

Cansian et al. (2013) confirmed the influence of the chloroform fraction of the stem of T. micranthus on Lactuca sativa seeds hypocotyl germination and growth, indicating its allelopathic potential. More recently, another research group, also led by Cansian, showed that the residual hydroalcoholic fraction from $T$. micranthus protects erythrocytes against oxidative damage, using an enzymatic in vitro assay to evaluate the action of the enzyme tyrosinase, suggesting its application in hypopigmentation disorders (Cansian et al., 2014a).

More recently, Cansian et al., (2014b) showed that mice treated with the extract presented a significant reduction in the latency time for mounts and an increased frequency of mounts, especially after three hours of treatment, in a dose-related manner, as compared to the control group. These results demonstrate the influence of T. micranthus on the sexual behavior of mice and allow the inclusion of this species in the list of aphrodisiac plants of the genus.

\section{Tynanthus panurensis (Bureau) Sandwith}

In the Peruvian Amazon, T. panurensis has been traditionally used as an aphrodisiac, energizing tonic and analgesic, as well as for the treatment of rheumatism and diabetes (Brack, 1999). In Brazil, this species is found in the northern region (Amazonas and Pará) (Lohmann, 2014e).

Studies by Plaza and colleagues (2005) have revealed, by LC-MS of the methanolic extract, the presence of the phenylpropanoid glycosides eugenol- $O$ $[\beta$-D-xylopyranosyl-( $(1 \rightarrow 5)-O-\beta$-D-apiofuranosyl- $(1 \rightarrow 6)$ $O$ - $\beta$-D-glucopyranosideverbascoside, leucosceptoside, isoverbascoside and the flavonoid katchimoside, apigenin8 -C-[ $\beta$-D-xylopyranosyl- $(1 \rightarrow 6)-\beta$-D-glucopyranoside (Figure 2).
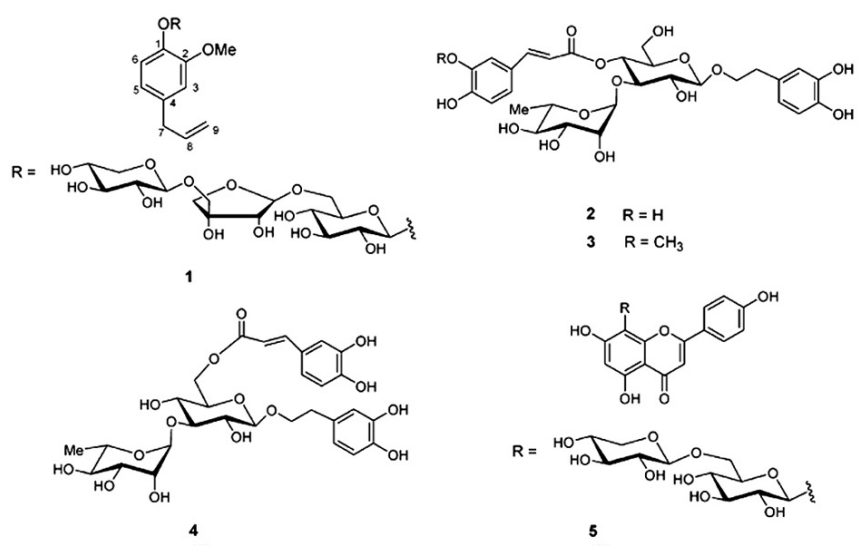

FIGURE 2 - Compounds isolated from the bark of Tynanthus panurensis. (1) Eugenol-O-[ $\beta$-D-xylopyranosyl- $(1 \rightarrow 5)-\mathrm{O}-$ $\beta$-D-apiofuranosyl- $(1 \rightarrow 6)-\mathrm{O}-\beta$-D-glucopyranoside, $(2)$ verbascoside, (3) leucosceptoside, (4) isoverbascoside and (5) katchimoside (apigenin 8-C-[ $\beta$-D-xylopyranosyl- $(1 \rightarrow 6)-\beta$-Dglucopyranoside) (Plaza et al., 2005).

Based on reports about the use of $T$. panurensis for the treatment of rheumatism, Morales et al. (2011) 
performed a study that aimed to demonstrate the antiinflammatory and antioxidant activity of the extract from the bark of this plant. In vitro assays showed that the extract possessed antioxidant properties and reduced microsomal lipid peroxidation, as well as uric acid and tumor necrosis factor (TNF) synthesis. Its powerful anti-inflammatory property was confirmed by the in vivo carrageenaninduced paw edema tests in rats, indicating that the bark extracts of $T$. panurensis actually have a beneficial effect in the treatment of inflammation, in accordance with the main traditional uses of this plant.

\section{Tynanthus schumannianus (Kuntze) A.H. Gentry}

This species is found in Bolivia, in the La Paz and Santa Cruz regions (Tropicos, 2014b) and in Brazil, in the northern (Acre, Amazonas, Pará and Rondônia) and northeastern (Maranhão) regions (Lohmann, 2014f).

In the Covendo region of Bolivia, the population uses this plant for the treatment of diarrhea, by drinking a tea which is made with pieces of stem and some fruits
(Quintana, Vargas, 1995). This traditional use indication motivated Muñoz et al. (2000) to include this species in their research, which evaluated the anti-malarial activity of some Bolivian plants used by the Mosetene Indians for the cure of several diseases. The residue from the fruit extract of T. schumannianus, obtained from maceration with ethanol-water, showed moderate activity in vivo $(49 \%$ with $510 \mathrm{mg} / \mathrm{kg})$ in rodents with malaria caused by Plasmodium vinckei petteri, and excellent in vitro activity ( $98 \%$ with $10 \mathrm{mg} / \mathrm{mL}$ ) against Plasmodium falciparum, comparable to the standard drug, chloroquine.

\section{DISCUSSION}

Of the 15 recognized species, only $T$. fasciculatus, T. guatemalensis, T. micranthus and T. panurenses have information about their chemical characteristics, allowing the detection of some common chemical groups, such as flavonoids, phenylpropanoids and steroids (Table II).

Eugenol and its derivatives are found in the majority of species with a delineated phytochemical profile. Studies

TABLE II - Chemical groups and isolated substances of species from the genus Tynanthus

\begin{tabular}{lccc}
\hline Species & Chemical groups & Identified substances & References \\
& Tannins, flavonoids & $\beta$-sitosterol- $\beta$-D-glucoside, & \\
& and cardiotonic & coumarin, stigmasterol, & Carvalho et al., 2009; \\
T. fasciculatus (Vell.) Miers & melilotic acid ethyl ester, & Vilegas et al., 1993; \\
& phenylpropanoids and & melilotic acid, melilotic & Vilegas et al., 1994 \\
& steroids & acid-O- $\beta$ - D- glucopyranoside & (melilotoside) \\
\hline
\end{tabular}

Saponins, anthocyanins and flavonoids, in the stem;

T. guatemalensis Donn. Sm benzoic acid derivatives, C-glycosyl flavonoids and phenylpropenes katchimoside analogs, 4-hydroxybenzoate, salicylic acid and eugenol

Miranda-Cruz, et al., 2012; Ferrier, 2014

\section{Flavonoids}

(dihidroflavonoids and leucoanthocyanins),

T. micranthus Mello ex K. Schum steroids and/ or triterpenes, anthraquinones heterosides, eugenol

\begin{tabular}{|c|c|c|c|}
\hline $\begin{array}{l}\text { T. panurensis (Bureau) } \\
\text { Sandwith }\end{array}$ & $\begin{array}{c}\text { Phenylpropanoid glycoside } \\
\text { and flavonoid }\end{array}$ & $\begin{array}{c}\text { Eugenol-O- }[\beta \text {-D- } \\
\text { xylopyranosyl- }(1 \rightarrow 5)-\mathrm{O}-\beta \text {-D- } \\
\text { apiofuranosyl- }(1 \rightarrow 6)-\mathrm{O}-\beta \text { - } \\
\text { D-glucopyranoside, } \\
\text { verbascoside, leucosceptoside, } \\
\text { isoverbascoside and } \\
\text { katchimoside (apigenin } \\
8 \text {-C- }[\beta \text {-D-xylopyranosyl- } \\
(1 \rightarrow 6)-\beta \text {-D-glucopyranoside })\end{array}$ & Plaza et al., 2005 \\
\hline
\end{tabular}

$$
\beta \text {-sitosterol, apigenin }
$$

Cansian et al., 2012;

Custódio et al., 2010 
have shown aphrodisiac activity in some plants such as cloves (Syzygium aromaticum) and nutmeg (Myristica fragrans). These plants have eugenol-rich essential oils, as do some species of the genus Tynanthus. Despite this evidence, no study has related the aphrodisiac activity of these species with the eugenol content.

In addition, T. guatemalensis and T. panurenses have both exhibited verbascoside and katchimoside in their chemical composition; the latter is an apigenin-derived flavonoid, a substance which is present on T. micranthus. T. guatemalensis and T. panurenses have traditional uses for the treatment of diabetes; however, there have been no studies relating this activity to compounds common to these species.

The chemical constitution of the genus Tynanthus follows the same pattern described for the Bignoniaceae family, as shown by Cipriani et al. (2012), who performed data collection on the chemical profile of this family. This study lists the most predominant metabolites in the studied species, starting with terpenoids, followed by special aromatic derivatives, quinones and flavonoids.

Some plant groups show a variety of chemical components, which can be used as taxonomic markers, since common characteristics in secondary metabolism can indicate kinship among species, beyond morphological similarities (Hegnauer, 1986). Although the number of publications is continually increasing, only a small proportion of plants have been chemically investigated, such as the genus studied in this review, rendering the available information insufficient. Hence, this study contributes to future investigations on the chemical taxonomic aspects of species of the genus Tynanthus.

The species T. fasciculatus, T. guatemalensis, T. micranthus and T. panurenses, besides having their phytochemical profile delineated, have been studied regarding their biological and pharmacological activities. Most of these studies were based on their traditional uses; for example, T. fasciculatus is an aphrodisiac plant whose application promoted studies that evaluated the influence of its extracts on the male reproductive organs of adult Wistar rats (Melo et al. 2010). Besides T. fasciculatus, T. micranthus and T. panurenses are also traditionally used for aphrodisiac purposes, although no study has demonstrated the chemical component and the mechanism responsible for this activity.

Table III shows a list of species, which have biological and pharmacological studies and their relationship between traditional and scientific uses.

Among all studied species, T. cognatus (Cham.) Miers and T. elegans Miers have related studies, although they do not mention their chemical composition, and only refer to morphological and phytosociological aspects.

This analysis allowed us to appreciate the deficiency of studies involving the toxicity of plants of the genus Tynanthus, a very important parameter when the subjects are plants which are routinely used by the population. Only T. fasciculatus and T. micranthus have been evaluated and showed a certain degree of toxicity against the microcrustacean Artemia salina, which may argue against the indiscriminate use of these plants.

TABLE III - List of species from the genus Tynanthus with traditional use indications, as well as studies related to biological and pharmacological activities

\begin{tabular}{|c|c|c|c|}
\hline Species & Traditional Use & $\begin{array}{c}\text { Biological and pharmacological } \\
\text { studied activities }\end{array}$ & References \\
\hline $\begin{array}{l}\text { Tynanthus fasciculatus (Vell.) } \\
\text { Miers }\end{array}$ & $\begin{array}{l}\text { Carminative, anthelmintic, } \\
\text { stimulant and aphrodisiac }\end{array}$ & $\begin{array}{l}\text { Male reproductive organs } \\
\text { morphometry anthelmintic } \\
\text { activity }\end{array}$ & $\begin{array}{l}\text { Farmacopéia, 1929; Correa, } \\
\text { 1974; Vilegas et al., 1993; } \\
\text { Melo et al., 2010; Amorim et } \\
\text { al., 1991 }\end{array}$ \\
\hline $\begin{array}{l}\text { Tynanthus guatemalensis Donn. } \\
\text { Sm }\end{array}$ & Diabetes & $\begin{array}{c}\text { Antimicrobial activity and } \\
\text { diabetes }\end{array}$ & $\begin{array}{c}\text { Ferrier, 2013; Miranda-Cruz et } \\
\text { al., } 2012 \\
\end{array}$ \\
\hline $\begin{array}{l}\text { Tynanthus micranthus Mello ex } \\
\text { K. Schum }\end{array}$ & Aphrodisiac & $\begin{array}{l}\text { Antimicrobial, allelopathic and } \\
\text { antioxidant activity, tyrosinase } \\
\text { stimulant and aphrodisiac } \\
\text { activity }\end{array}$ & $\begin{array}{l}\text { Custódio et al., 2010; Cansian } \\
\text { et al., 2012; Cansian, et al., } \\
\text { 2013; Cansian et al., 2014a; } \\
\text { Cansian et al., 2014b }\end{array}$ \\
\hline $\begin{array}{l}\text { Tynanthus panurensis (Bureau) } \\
\text { Sandwith }\end{array}$ & $\begin{array}{l}\text { Aphrodisiac, energizing tonic, } \\
\text { analgesic, for the treatment of } \\
\text { rheumatism and diabetes }\end{array}$ & $\begin{array}{l}\text { Antioxidant and anti- } \\
\text { inflammatory activity }\end{array}$ & $\begin{array}{c}\text { Brack, 1999; Morales et al., } \\
2011\end{array}$ \\
\hline
\end{tabular}




\section{CONCLUSION}

During the assessment of all the data incorporated into this review, it became possible to verify the deficiency of studies involving the majority of species of the genus Tynanthus. Also, it was observed that some members have potential for their use, because they are already known and traditionally used, but need to be better evaluated with respect to their toxicity.

Hence, this work contributes significantly to research fields which aim to identify potential plants which are insufficiently explored, in order to delineate their chemical profile and possible biological activities and thus contribute to the discovery of natural substances which may serve as the basis for the development of new drugs and cosmetics, among other beneficial products for the population.

\section{ACKNOWLEDGMENTS}

The authors thank CAPES for the financial support, and are grateful for support from the Pharmaceutical Sciences Post-Graduation Course Department Coordination of the Federal University of Paraná.

\section{CONFLICTS OF INTEREST}

There have been no conflicts of interest in carrying out this work.

\section{REFERENCES}

AMORIM, A.; BORBA, H.R.; AMANO, L.M. Ação antihelmíntica de plantas IV. Influência da casca do caule do cipó-cravo (Tynnantus fasciculatus, Miers, Bignoniaceae) na eliminação de Vampirolepis nana e oxiurídeos em camundongos. Rev. Bras. Farm., v.72, n.4, p.92-94, 1991.

BRACK, E.A. Diccionario enciclopédico de plantas utiles del Perú. Cusco: Centro de Estudios Regionales, Andinos Bartolomé de las Casas, 1999. p.508-509.

BUREAU, M.E. Revisión des genres Tynanthus et Lundia. Adansonia (Baillon). Adansonia, v.8, p.270-294, 1868.

CANSIAN, F.C.; MIGUEL, M.D.; MIGUEL, O.G.; MIYASAKI, C.M.S.; LIMA, C.P.; KALEGARI, M.; MERINO, F.J.Z.; SOUZA, A.M.; COGO, L.L. Phytochemical, toxicity and microbiological activity study of Tynanthus micranthus Corr. Mello ex Schum. (Bignoniaceae). Lat. Am. J. Pharm., v.31, n.3, p.487-491, 2012.
CANSIAN, F.C.; LIMA, C.P.; ZORTÉA, F.M.; MIGUEL, O.G.; MIGUEL, M.D. Potencial alelopático de Tynanthus micranthus Corr. Mello ex. Schum. (Bignoniaceae) sobre diásporos de Lactuca sativa L. Rev. Ciênc. Farm. Básica Apl., v.34, n.4, p.137-140, 2013.

CANSIAN, F.C.; SILVA, C.B.; LIMA, C.P.; MERINO, F.J.Z.; RECH, K.S.; OTUKI, M.F.; CAMPOS, P.M.; MIGUEL, O.G.; MIGUEL, M.D. Tynanthus micranthus: an efficient antioxidant and tyrosinase activity inductor. Afr. J. Pharm. Pharmacol., v.8, n.23, p.651-657, 2014a.

CANSIAN, F.C., MERINO, F.J.Z., AMARAL, V.L.L., SALVADOR, R.A., CAMPOS, P.M., MONTRUCCHIO, D.P., MIGUEL, O.G., MIGUEL, M.D. Aphrodisiac properties of Tynanthus micranthus Corr. \& Mello ex. Schum in male mice. Afr. J. Pharm. Pharmacol., v.8, n.47, p.1200-1204, 2014b.

CARVALHO, C.A.; MATTA, S.L.P.; MELO, F.C.S.A.; ANDRADE, D.C.F.; CARVALHO, L.M.C.; NASCIMENTO, P.C; SILVA. M.B.; ROSA, M.B. Cipócravo (Tynnanthus fasciculatus Miers - Bignoniaceae): estudo fitoquímico e toxicológico envolvendo Artemia salina. Rev. Elet. Farm., v.6, n.1, p.51-57, 2009.

CIPRIANI, F.A.; FIGUEIREDO, M.R.; SOARES, G.L.G.; KAPLAN, M.A.C. Implicações químicas na sistemática e filogenia de Bignoniaceae. Quím. Nova, v.35, n.11, p.21252131, 2012.

CORREA, M.P. Dicionário das plantas úteis do brasil e das exóticas cultivadas. 1.ed. Rio de Janeiro: IBDF, 1974. 687 p.

CUSTÓDIO, D.L.; BURGO, R.P.; MORIEL, B.; BARBOSA, A.M.; REZENDE, M.I.; DANIEL, J.F.S.; PINTO, J.P.; BIANCHINI, E.; FARIA, T.J. Antimicrobial activity of essential oils from Piment pseudocaryophyllus and Tynanthus micranthus. Braz. Arch. Biol. Technol., v.53, n.6, p.1363-1369, 2010.

DI STASI, L.C.; HIRUMA-LIMA, C.A. Plantas medicinais na amazônia e na mata atlântica. 2.ed. São Paulo: UNESP, 2002. p.449-450.

FARMACOPÉIA dos Estados Unidos do Brasil. 1.ed. São Paulo: Cia Editora Nacional, 1929. 1149 p. 
FERRIER, J.; CARTER-RAMIREZ, A.; PESEK, T.; CAL, V.; BALICK, M.J.; ARNASON, J.T. K'an, Tynanthus guatemalensis Donn. Sm.: the taxonomic and archeological mystery behind a maya antidiabetic medicinal plant (Invited). In: Natural health product research society of Canada, 2013. Ontario, 2013. Available at: <https://www. mendeley.com/research/kan-tynanthus-guatemalensisdonnsm-taxonomic-archeological-mystery-behind-mayaantidiabetic-medicina>. Accessed on: 27 June 2013.

FERRIER, J. Ethnobotany, pharmacology, and metabolomics of antidiabetic plants used by the Eeyou Istchee Cree, Lukomir Highlanders, and Q'eqchi'Maya. Canada, 2014. 193 p. [Dissertation of master degree. Faculty of Graduate and Postdoctoral Studies. University of Ottawa].

FISCHER, E.; THEISEN, I.; LOHMANN, L.G. Bignoniaceae. In: KADEREIT, J.W. The families and genera of vascular plants. Lamiales, v.VII, p.9-38. Berlin: Springer-Verlag, 2004

GENTRY, A.H. Bignoniaceae. Part I: Crescentieae and Tourrettieae. New York: The New York Botanical Garden, 1980. 130 p. (Monograph number, 25).

HEGNAUER, R. Phytochemistry and plant taxonomy-an essay on the chemotaxonomy of higher plants. Phytochemistry, v.25, n.7, p.1519-1535, 1986.

HORA, R.C.; SOARES, J.J. Estrutura fitossociológica da comunidade de lianas em uma floresta estacional semidecidual na Fazenda Canchim, São Carlos, SP. Rev. Bras. Bot., v.25, n.3, p.323-329, 2002.

LIMA, A.; PACE, M.; ANGYALOSSY, V. Seasonality and growth rings in lianas of Bignoniaceae. Trees, v.24, n.6, p.1045-1060, 2010.

LOHMANN, L.G. Untangling the phylogeny of neotropical lianas (Bignonieae, Bignoniaceae). Am. J. Bot., v.93, n.2, p.304-318, 2006.

LOHMANN, L.G.; ULLOA, C.U. Bignoniaceae. In: iPlants prototype checklist, 2007. Available at: http://www.iplants. org. Accessed on: 21 Apr. 2013.

LOHMANN, L.G. Bignoniaceae. In: List of species of the Brazilian flora. Rio de Janeiro Botanical Garden. Available at: <http://reflora.jbrj.gov.br/jabot/floradobrasil/ FB113967>. Accessed on: 30 July 2014a.
LOHMANN, L.G. Bignoniaceae. In: List of species of the Brazilian flora. Rio de Janeiro Botanical Garden. Available at: <http://reflora.jbrj.gov.br/jabot/floradobrasil/ FB113968>. Accessed on: 30 July 2014b.

LOHMANN, L.G. Bignoniaceae. In: List of Species of the Brazilian flora. Rio de Janeiro Botanical Garden. Available at: <http://reflora.jbrj.gov.br/jabot/floradobrasil/ FB113969>. Accessed on: 30 July 2014c.

LOHMANN, L.G. Bignoniaceae. In: List of species of the Brazilian flora. Rio de Janeiro Botanical Garden. Available at: <http://reflora.jbrj.gov.br/jabot/floradobrasil/ FB113974>. Accessed on: 30 July 2014d.

LOHMANN, L.G. Bignoniaceae. In: List of species of the Brazilian flora. Rio de Janeiro Botanical Garden. Available at: <http://reflora.jbrj.gov.br/jabot/floradobrasil/ FB113976>. Accessed on: 30 July 2014e.

LOHMANN, L.G. Bignoniaceae. In: List of species of the Brazilian flora. Rio de Janeiro Botanical Garden. Available at: <http://reflora.jbrj.gov.br/jabot/floradobrasil/ FB113979>. Accessed on: 30 July 2014f.

LOPES, M.M.M.; CARVALHO-OKANO, R.M.; SOUZA, A.L.; PAIVA, H.N. Seedling growth of clove vine (Tynanthus fasciculatus miers), a liana with medicinal potential. Rev. Árvore, v.32, n.2, p.211-216, 2008.

MELO, F.C.S.A.; MATTA, S.L.P; PAULA, T.A.R.; GOMES, M.L.M.; OLIVEIRA, L.C. The effects of Tynnanthus fasciculatus (Bignoniaceae) infusion on testicular parenchyma of adult Wistar rats. Biol. Res., v.43, n.4, p.445-450, 2010.

MIERS, J. Report on the plants collected by Mr. Weir, especially the Bignoniaceae. Proceedings of the Royal Horticultural Society of London, v.3, p.193, 1863.

MIRANDA-CRUZ, E.; CENTURIÓN-HIDALGO, D.; VELÁZQUEZ-MARTÍNEZ, J.R.; ALOR-CHÁVEZ, M.J. Antimicrobial activity of Psidium friedrichsthalianum L., Pterocarpus hayesii L., Tynanthus guatemalensis L. and Spondias purpurea L. extracts. Bol. Latinoam. Caribe Plantas Med. Aromát., v.11, n.4, p.354-361, 2012. 
MORALES, L.; ACERO, N.; GALÁN, A.; PÉREZ-GARCIA, C.; ALGUACIL, L.F.; MUÑOZ-MINGARRO, D. Bioactive properties of Tynanthus panurensis (Bureau) Sanwith bark extract, the Amazonian "clavo huasca". J. Med. Food, v.14, n.9, p.939-943, 2011.

MUÑOZ, V.; SAUVAIN, M.; BOURDY, G.; CALLAPA, J.; ROJAS, I.; VARGAS, L.; TAE, A.; DEHARO, E. The search for natural bioactive compounds through a multidisciplinary approach in Bolivia. Part II. Antimalarial activity of some plants used by Mosetene Indians. J. Ethnopharm., v.69, n.2, p.139-155, 2000.

OLMSTEAD, R.G.; ZJHRA, M.L.; LOHMANN, L.G; GROSE, S.O.; ECKERT, A.J. A molecular phylogeny and classification of Bignoniaceae. Am. J. Bot., v. 96, n.9, p.1731-1743, 2009.

PLAZA, A.; MONTORO, P.; BENAVIDES, A.; PIZZA, C.; PIACENTE, S. Phenylpropanoid glycosides from Tynanthus panurensis: characterization and LC-MS quantitative analysis. J. Agric. Food Chem., v.53, n.8, p.2853-2858, 2005.

QUINTANA, P.G.; VARGAS, R.L. Guía popular de plantas utilizadas por los Mosetenes de Covendo, Santa Ana, y Muchanes. (Alto Beni, Bolivia). La Paz: Fonama, 1995. 186p. apud MUÑOZ, V.; SAUVAIN, M.; BOURDY, G.; CALLAPA, J.; ROJAS, I.; VARGAS, L.; TAE, A.; DEHARO, E. The search for natural bioactive compounds through a multidisciplinary approach in Bolivia. Part II. Antimalarial activity of some plants used by Mosetene Indians. J. Ethnopharmacol., v.69, n.2, p.139-155, 2000.

REITZ, P.R. Bignoniaceae. In: Flora catarinense. Itajaí: Herbário Barbosa Rodrigues, 1974. 172 p.
SOUZA, L.A.; SANTOS, G.O.; MOSCHETA, I.S. Morfoanatomia floral de espécies lianescentes de Bignoniaceae. Iheringia, Sér. Bot., v.65, n.1, p.5-15, 2010.

SPANGLER, R.E.; OLMSTEAD, R.G. Phylogenetic analysis of Bignoniaceae based on the cpDNA gene sequences of, $r b c$ L and $n d h$ F. Ann. Missouri Bot. Gard., v.86, p.33-46, 1999.

TAJUDDIN, S.A.; LATIF, A.; QASMI, I.A. Aphrodisiac activity of 50\% ethanolic extracts of Myristica fragrans Houtt. (nutmeg) and Syzygium aromaticum (L) Merr. \& Perry. (clove) in male mice: a comparative study. $B M C$ Complement. Altern. Med., v.3, n.6, p.1-5, 2003.

TROPICOS. Missouri Botanical Garden. Available at: $<$ http:// www.tropicos.org/Name/3701480>. Accessed on: 30 July 2014a.

TROPICOS. Missouri Botanical Garden. Available at: $<$ http:// www.tropicos.org/Name/3701425>. Accessed on: 30 July 2014b.

VILEGAS, J.H.Y.; VILEGAS, W.; POZETTI, G.L.; LLABRES, G. Constituents of Tynanthus fasciculatus. Fitoterapia, v.64, n.5, p.476, 1993.

VILEGAS, W.; VILEGAS, H.Y.; POZETTI, G.L.; MORENO, R.M.S. The chemistry of "cipócravo"- Tynanthus fasciculatus. Rev. Latinoam. Quím., v.23, n.2, p.47-49, 1994.

Received for publication on $08^{\text {th }}$ September 2014 Accepted for publication on $02^{\text {nd }}$ July 2015 
